\title{
CORRIGENDUM
}

\section{Comparative performance of the stable isotope signatures of carbon, nitrogen and oxygen in assessing early vigour and grain yield in durum wheat - CORRIGENDUM}

J. BORT ${ }^{1}$, M. BELHAJ ${ }^{2}$, K. LATIRI ${ }^{2}$, Z. KEHEL ${ }^{3}$ AND J. L. ARAUS ${ }^{1}$

DOI: http://dx.doi.org/10.1017/S0021859613000269, published by Cambridge University Press, 23 May 2013.

The names and affiliations for this paper should read:

J. BORT ${ }^{1 *}$, M. BELHAJ FRAJ ${ }^{2,3+}$, K. LATIRI $^{2}$, Z. KEHEL ${ }^{4}$ AND J. L. ARAUS ${ }^{1}$

${ }^{1}$ Plant Biology Department, Faculty of Biology, University of Barcelona, Diagonal 643, 08028 Barcelona, Spain

2 ICBA, International Center for Biosaline Agriculture, PO BOX 14660, Dubai, UAE

${ }^{3}$ INRAT, Field Crops Lab, Rue Hédi Karray, 2049 Ariana, Tunisia

${ }^{4}$ Biodiversity and Integrated Gene Management, International Centre for Agricultural Research in the Dry Areas

(ICARDA), PO Box 5466, Aleppo, Syria

* To whom all correspondence should be addressed. Email: jordi.bort@ub.edu

+ Present address: ICBA, International Center for Biosaline Agriculture, PO BOX 14660, Dubai, UAE

\section{REFERENCE}

Bort, J., Belhaj Fraj, M., Latiri, K., Kehel, Z. \& Araus, J. L. (2013). Comparative performance of the stable isotope signatures of carbon, nitrogen and oxygen in assessing early vigour and grain yield in durum wheat. Journal of Agricultural Science, Cambridge, http://dx.doi.org/10.1017/S0021859613000269 